\title{
Pengaruh Penilaian Tingkat Kesehatan Bank Terhadap Praktik Manajemen Laba Pada Bank Umum Syariah di Indonesia
}

\author{
The effect of bank soundness level on earnings management practices in Islamic banks in \\ Indonesia
}

\section{Salma Cantya Paramastri}

Program Studi D4 Keuangan Syariah, Politeknik Negeri Bandung

E-mail: salmacantya@gmail.com

\section{Radia Purbayati}

Jurusan Akuntansi, Politeknik Negeri Bandung

E-mail: radia.purbayati@polban.ac.id

\section{Dimas Sumitra Danisworo}

Jurusan Akuntansi, Politeknik Negeri Bandung

E-mail: dimas.danisworo@polban.ac.id

\begin{abstract}
Earnings management is carried out to show that the company is in good condition even though in reality it is not good. These practices are not in accordance with sharia principles. This study aims to determine the effect of the Bank. Soundness Level Assessment using the RGEC method on earnings management practices in Islamic Commercial Banks in Indonesia for the 2015 2018 period. The variables used are the Financing to Deposit Ratio (FDR), Return On Assets (ROA), Good Corporate Governance (GCG), and Capital Adequacy Ratio (CAR). Testing the variables using the Path Analysis method with a sample of 9 Islamic Commercial Banks in Indonesia. The results showed that the FDR and CAR variables had a negative and significant effect; $R O A$ bas a positive and insignificant effect; and GCG bas a negative and insignificant effect on earnings management practices at Islamic Commercial Banks in Indonesia.
\end{abstract}

Keywords: earnings management, bank soundness level, Islamic commercial bank

\section{Pendahuluan}

Dalam dunia bisnis, perusahaan berlomba-lomba menampilkan perkembangan yang baik dengan menunjukkan tingkat keuntungan yang semakin meningkat setiap tahunnya. Hal ini bertujuan agar para investor menanamkan dananya dan menambah modal perusahaan. Dana yang telah didapatkan kemudian akan digunakan untuk kegiatan operasional perusahaan. Tidak dapat dipungkiri bahwa dalam dunia bisnis, ada kemungkinan terjadinya fluktuasi dalam laba yang akan didapatkan oleh perusahaan. Dalam suatu periode, perusahaan memiliki peluang untuk mendapatkan laba yang besar, sedangkan pada periode lain perusahaan memiliki kemungkinan mengalami kerugian. Ketika perusahaan tidak dalam kondisi baik atau terjadi penurunan laba, hal tersebut memungkinkan adanya investor yang menarik dananya dari perusahaan karena kerugian yang didapatkan. Sehingga, perusahaan dituntut untuk menampilkan kondisi perusahaan yang baik dalam laporan keuangan untuk menghindari terjadinya hal tersebut. Hal ini yang kemudian memicu terjadinya praktik manajemen laba pada perusahaan. Manajemen laba (Earnings Management / إدارة merupakan kebijakan atau tindakan yang dilakukan oleh manajer akuntansi untuk 
mempengaruhi pendapatan perusahaan dengan tujuan pencapaian tertentu (Scott, 2009).

Manajemen laba telah terbukti dilakukan beberapa perusahaan untuk menutupi kondisi perusahaan yang sedang buruk (Prakarsa \& Setiawan, 2018). Salah satu perusahaan besar di Indonesia terbukti telah menjalankan manajemen laba pada tahun 2007, yaitu PT.AGIS Tbk. Dilansir pada halaman resmi Tempo Bisnis, Badan Pengawas Pasar Modal dan Lembaga Keuangan (BAPEPAM-LK) memberikan penalti sebesar Rp 5 Miliar kepada Direktur Utama PT.AGIS Tbk. atas ketidakbenaran informasi yaitu pendapatan 2 (dua) perusahaan yang akan dilakukan alih kepemilikan yaitu PT.Akira Indonesia dan PT.TT Indonesia. Pihak AGIS melaporkan bahwa kedua perusahaan tersebut memiliki pendapatan sebesar Rp 800 Miliar, dimana kenyataannya pada Laporan Keuangan kedua perusahaan total pendapatan kurang lebih Rp 466,8 Miliar. Selain itu, terdapat ketidakwajaran pada Laporan Keuangan AGIS Elektronik yang mengakibatkan ketidakwajaran pada Laporan Keuangan Konsolidasian AGIS (Tempo, 2007). Praktik manajemen laba terjadi tidak hanya pada perusahaan indutri namun juga terindikasi pada perbankan. Penelitian oleh (Zoubi \& Al-Khazali, 2007) pada wilayah Gulf Cooperation Council (GCC) yang terdiri dari Kuwait, United Arab Emirates (UAE), Qatar, Bahrain, Arab Saudi, dan Oman meneliti manajemen laba pada bank syariah yang diketahui dilakukan oleh manajer bank di wilayah tersebut dengan merubah konstruksi pada nilai cadangan kerugian (loan loss provisions) dengan tujuan tertentu yang terindikasi dari nilai rasio Return On Assets (ROA) sebelum pajak dan cadangan kerugian. Pada negara Arab Saudi sendiri terjadinya manajemen laba diteliti lebih lanjut oleh (Habbash \& Alghamdi, 2015) yang meneliti perusahaan publik dan mendapatkan hasil bahwa manajemen laba dilakukan pada perusahaan publik dengan motivasi untuk meningkatkan jumlah remunerasi, melaporkan keuntungan yang wajar dan menghindari kerugian, serta untuk mendapatkan pinjaman dan menaikkan harga saham perusahaan. Penelitian oleh (Jasman, 2015) yang melakukan penelitian pada perbankan yang terdata secara resmi oleh Bursa Efek Indonesia (BEI), didapatkan hasil yaitu bank di Indonesia menjalankan praktik manajemen laba dengan variabel bebas yaitu efektivitas dewan komisaris dan efektivitas komite audit, belum terbukti meminimalisir terjadinya manajemen laba. Sedangkan pada penelitian lain, pelaksanaan manajemen laba pada bank konvensional memiliki nilai berbeda dengan manajemen laba pada bank syariah yaitu bank konvensional melakukan manajemen laba lebih besar daripada bank syariah (Pujiati \& Wahyuningsih, 2016). Penelitian lain oleh (Muhammad, 2017) pada Bank BNI Syariah baik pada tahun 2013 maupun tahun 2014 ditemukan telah melakukan praktik manajemen laba dengan menaikkan pelaporan laba akrualnya. Hal serupa ditemukan oleh (Nasution, 2017) yang melakukan studi kasus pada Bank Panin Syariah dengan menguji faktor yang berpengaruh yaitu rasio Financing to Deposit Ratio (FDR), Return On Asset (ROA), dan Ukuran Perusahaan. Faradila \& Cahyati (2013) juga memperoleh hasil bahwa 11 bank syariah di Indonesia terbukti menurunkan laba yang dilaporkan sebagai cara melakukan praktik manajemen laba pada tahun 2011-2012.

Praktik manajemen laba dapat disebabkan oleh berbagai faktor yang menuntut perusahaan untuk menampilkan laporan keuangan dalam kondisi yang baik walaupun perusahaan sedang dalam kondisi berlawanan. Indonesia sendiri menetapkan bahwa perbankan di Indonesia harus melakukan penilaian tingkat kesehatan bank berdasarkan Peraturan Bank Indonesia (PBI) Nomor 13/1/PBI/2011 perihal Penilaian Tingkat Kesehatan Bank Umum. Berdasarkan peraturan tersebut, perbankan diharuskan melaksanakan penilaian tingkat kesehatan bank secara individual dan konsolidasi setiap semester. Penilaian akan menghasilkan peringkat komposit yang menggambarkan kondisi kesehatan bank. Dengan penetapan peraturan ini diduga manajemen laba dilakukan untuk memenuhi kriteria penilaian dan memperoleh hasil penilaian yaitu perbankan dalam keadaan sehat. Sejak 2011, penilaian tingkat kesehatan menggunakan metode RGEC yaitu Profil Risiko (Risk Profile), Tata Kelola Perusahaan yang Baik (Good Corporate Governance), Rentabilitas (Earnings), dan Permodalan (Capita). Berdasarkan penelitian oleh Lestari et al. (2020) 
penggunaan metode RGEC juga dapat memprediksi financial distress dengan tingkat keakuratan sebesar 36,1\% pada Bank Umum Syariah. Sehingga, metode RGEC saat ini umum digunakan untuk mengungkap kecurangan dalam bank dan sebagai alat ukur dalam penilaian tingkat kesehatan bank.

Berdasarkan pemaparan dan berbagai penelitian diatas, terdapat bukti bahwa bank syariah menjalankan manajemen laba untuk berbagai tujuan. Penelitian oleh Suhartanto et al., (2018) meneliti beberapa faktor yang memberikan dampak pada kesetiaan nasabah pada Bank Umum Syariah, salah satunya yaitu tingkat kepercayaan yang didukung oleh religiusitas yaitu prinsip Islam yang digunakan bank sejalan dengan prinsip yang diyakini oleh nasabah. Namun, bukti yang ada tidak selaras dengan prinsip bank syariah yang berlandaskan Al-Qur'an dan Hadist yaitu seharusnya kegiatan bisnis dilakukan dengan jujur dan amanah. Jujur dalam pengelolaan dan pelaporan keuangan perusahaan serta amanah dalam pengelolaan dana yang dititipkan agar digunakan sebagaimana mestinya. Sehingga dipilih bank syariah sebagai subjek penelitian untuk mengetahui faktor yang mempengaruhi bank syariah menjalankan manajemen laba. Hal ini bertujuan untuk memperbaiki penilaian dalam bank agar kepercayaan nasabah dapat terjaga dengan baik. Praktik manajemen laba di Indonesia diduga dilakukan karena adanya evaluasi tingkat kesehatan bank yang dilakukan dengan metode RGEC. Melalui evaluasi tersebut akan dihasilkan peringkat komposit kesehatan bank yang menunjukkan kondisi kesehatan bank. Maka dari itu, untuk mendapatkan hasil yang 'sehat' maka perbankan memiliki tuntutan untuk menyediakan laporan keuangan yang termasuk dalam kriteria 'sehat' tersebut. Penelitian terdahulu yang telah dilakukan dan selaras dengan peneilitian ini menunjukkan hasil yang berbeda-beda dan jumlahnya masih minim. Penelitian yang akan dilakukan menggunakan data Laporan Keuangan Bank Umum Syariah rentang tahun 2015-2018, hal ini merupakan keberlanjutan dari beberapa penelitian terdahulu yang mayoritas menilai manajemen laba sampai tahun 2014. Penelitian ini bertujuan untuk mengetahui pengaruh dari Risk Profile, Good Corporate Governance, Earnings, dan Capital terhadap Praktik Manajemen Laba Pada Bank Umum Syariah di Indonesia.

\section{Kajian Pustaka}

\subsection{Manajemen Laba}

Manajemen laba adalah saat manajer melakukan pertimbangan untuk melakukan perubahan dalam merancang laporan keuangan dan penyusunan transaksi. Praktik ini dilakukan umumnya pada laporan yang harus dipublikasikan dan mengandung informasi yang memberikan pengaruh yang besar bagi perusahaan (Padmantyo, 2010). Perhitungan Total Akrual sebagai proksi Manajemen Laba menggunakan model Healy sebagai berikut:

$$
\mathbf{T A}_{\mathrm{it}}=\left(\mathrm{CA}_{\mathrm{it}}-\mathrm{CL}_{\mathrm{it}}-\mathrm{Cash}_{\mathrm{it}}+\mathrm{STD}_{\mathrm{it}}-\mathrm{Dep}_{\mathrm{it}}\right) / \mathbf{A}_{(\mathrm{it}-1)}
$$

Keterangan :

$\mathrm{TA}_{\mathrm{it}}=$ Total Akrual bank i pada periode ke $\mathrm{t}$

$\mathrm{CA}_{\mathrm{it}}=$ Perubahan aktiva lancar bank i pada periode ke $\mathrm{t}$

$\mathrm{CL}_{\mathrm{it}}=$ Perubahan utang lancar bank i pada periode ke $\mathrm{t}$

$\mathrm{Cash}_{\mathrm{it}}=$ Perubahan kas dan ekuivalen, bank i pada periode ke $\mathrm{t}$

$\mathrm{STD}_{\mathrm{it}}=$ Perubahan utang jangka panjang yang tercakup dalam utang lancar bank i pada periode ke $t$

Depit $_{\text {it }}=$ Biaya depresiasi bank i pada periode ke $\mathrm{t}$

$\mathrm{A}_{(\mathrm{it}-1)}=$ Total Aktiva bank i pada periode ke $\mathrm{t}-1$

\subsection{Penilaian Tingkat Kesehatan Bank}

Metode RGEC merupakan indikator penilaian kesehatan kinerja perbankan sesuai dengan Surat Edaran Bank Indonesia Nomor 13/24/DPNP yang diterbitkan pada 25 Oktober 2011. 
Penilaian dilakukan sendiri oleh bank (self assessment) baik secara individual maupun konsolidasi yang terdiri dari faktor Profil Risiko (Risk Profile), Tata Kelola Perusahaan yang baik (Good Corporate Governance), Rentabilitas (Earnings), dan Permodalan (Capital) untuk menghasilkan Peringkat Komposit Tingkat Kesehatan Bank.

\subsubsection{Financing To Deposit Ratio (FDR)}

Risiko Likuiditas diperhitungkan dengan rasio FDR yang membandingkan total pembiayaan dengan total dana pihak ketiga (DPK) yang diterima bank. Meningkatnya kegiatan pembiayaan memberikan dampak pada pendapatan pihak ketiga yang juga akan meningkat, hal ini kemudian berdampak pada peningkatan laba dan kinerja bank (Nahar \& Erawati, 2017). Peningkatan pada rasio FDR, mengindikasikan bank memiliki kemampuan yang rendah dalam hal likuiditas bank. Bank Indonesia menentukan batas FDR adalah antara 80\% hingga 110\%. Rasio FDR dapat dicari dengan rumus sebagai berikut:

$$
\text { Financing to Deposit Ratio }=\frac{\sum \text { Pembiayaan }}{\sum \text { Dana Pihak Ketiga (DPK) }} \times 100 \%
$$

\subsubsection{Good Corporate Governance (GCG)}

Perangkat aturan yang menjelaskan hubungan antara stakeholders internal dengan eksternal terkait hak dan kewajiban masing-masing pihak. Penilaian tata kelola perusahaan dilakukan secara mandiri (self assessment) oleh bank dan dihasilkan peringkat komposit yang menunjukkan kondisi tata kelola perusahaan yang baik. Peringkat komposit tersebut digunakan sebagai data dalam penelitian ini.

\subsubsection{Return On Assets (ROA)}

Kemampuan manajemen bank dalam memanfaatkan aktiva operasional perusahaan dengan maksimal dan memperoleh keuntungan secara keseluruhan dapat diukur menggunakan rasio ROA. Peningkatan ROA menunjukkan peningkatan produktifitas pengelolaan aset (Setiawati, 2010). Hal ini mempengaruhi kepercayaan investor terhadap perusahaan pada masa mendatang. Rumus untuk mencari ROA adalah :

\subsubsection{Capital Adequacy Ratio (CAR)}

$$
\text { Return On Asset }=\frac{\text { Laba Sebelum Zakat dan Pajak }}{\text { Total Asset }} \times 100 \%
$$

Tingkat kecukupan modal dalam bank diatur oleh Bank Indonesia untuk menjaga agar bank dapat melakukan penanganan atas risiko yang muncul pada kepemilikan aset oleh bank. Hal tersebut dapat diukur dengan rasio CAR. Pemberlakuan nilai minimun dalam rasio CAR diduga menarik terjadinya permainan pada laporan keuangan di industri perbankan. Laporan Keuangan bank mencantumkan rasio tersebut yang didapatkan dengan perhitungan sebagai berikut,

$$
\text { Capital Adequacy Ratio }=\frac{\text { Modal }}{\text { ATMR }} \times 100 \%
$$

\subsection{Hubungan Antar Variabel}

\subsubsection{Financing to Deposit Ratio (FDR) terhadap Manajemen Laba}

Rasio FDR sebagai indikator kondisi pembiayaan menunjukkan perkembangan pembiayaan dalam bank. Peningkatan pada rasio FDR menunjukkan semakin banyak pembiayaan yang tersalurkan. Hal ini menandakan bagi hasil yang diterima oleh bank dan pihak ketiga akan bertambah serta memotivasi manajemen bank untuk meningkatkan kinerjanya. Sehingga, 
peningkatan FDR diduga menurunkan praktik manajemen laba dengan meningkatnya pendapatan bank. (Nahar \& Erawati, 2017).

H1 : Financing to Deposit Ratio (FDR) berpengaruh negatif dan signifikan terhadap praktik manajemen laba pada Bank Umum Syariah di Indonesia.

\subsubsection{Good Corporate Governance (GCG) terhadap Manajemen Laba}

Perangkat aturan yang menjelaskan hubungan antara stakeholders internal dengan eksternal terkait hak dan kewajiban masing-masing pihak. GCG diterapkan untuk menjaga operasional bank tetap dalam pengawasan dan berjalan dengan baik tanpa melibatkan praktik kecurangan. Sehingga, dengan memiliki peringkat GCG yang baik, bank terhindar dari praktik manajemen laba.

H2 : Good Corporate Governance (GCG) berpengaruh negatif dan signifikan terhadap praktik manajemen laba pada Bank Umum Syariah di Indonesia.

\subsubsection{Return On Asset (ROA) terhadap Manajemen Laba}

Kemampuan manajemen bank dalam memanfaatkan aktiva operasional perusahaan dengan maksimal dan memperoleh keuntungan secara keseluruhan dapat diukur menggunakan rasio ROA. Pengelolaan aset yang semakin baik dapat ditunjukkan oleh rasio ROA (Setiawati, 2010). Rasio ini digunakan oleh investor sebagai bahan pertimbangan serta prediksi laba dan risiko sebelum membuat keputusan investasi. Sehingga, kondisi perusahaan dengan ROA rendah diduga memotivasi praktik manajemen laba dilakukan pada tahun selanjutnya dengan intensif untuk menarik investor. Melinda \& Setiawan (2020) menemukan pengaruh yang positif antara ROA dan manajemen laba.

H3 : Return On Asset (ROA) berpengaruh negatif dan signifikan terhadap praktik manajemen laba pada Bank Umum Syariah di Indonesia.

\subsubsection{Capital Adequacy Ratio (CAR) terhadap Manajemen Laba}

Tingkat kecukupan modal dalam bank diatur oleh Bank Indonesia untuk menjaga agar bank dapat melakukan penanganan atas risiko yang muncul pada kepemilikan aset oleh bank. Pemberlakuan nilai minimun dalam rasio CAR diduga menarik terjadinya praktik manajemen laba pada industri perbankan. Sehingga, semakin rendah nilai CAR diperkirakan praktik manajemen laba menjadi semakin intensif untuk memenuhi batas minimum.

H4 : Capital Adequacy Ratio (CAR) berpengaruh negatif dan signifikan terhadap praktik manajemen laba pada Bank Umum Syariah di Indonesia.

\section{Metode Penelitian}

\subsection{Metode Penelitian}

Penelitian kuantitatif merupakan jenis penelitian yang didasarkan pada penggunaan data-data dalam bentuk angka sebagai alat analisis dan kajian penelitian (Kasiram, 2008). Penelitian ini menggunakan pendekatan deskriptif dimana digunakan narasi dalam menggambarkan hasil pengolahan data. Sehingga, penelitian ini bersifat deskriptif kuantitatif dimana data penelitian berbentuk angka dan hasil pengolahan data digambarkan dalam bentuk narasi terkait pengaruh antar variabel.

\subsection{Objek, Subjek, dan Populasi Penelitian}

Populasi dari penelitian ini adalah Bank Umum Syariah (BUS) di Indonesia yang terdata secara resmi pada Otoritas Jasa Keuangan (OJK) periode tahun 2015 hingga tahun 2018. Subjek pada penelitian ini adalah 9 Bank Umum Syariah (BUS) di Indonesia yang beroperasi dan terdata secara resmi pada Otoritas Jasa Keuangan (OJK) pada tahun 2015 sampai dengan tahun 2018. Sehingga, 
subjek penelitian ini yaitu,

1. Bank Muamalat Indonesia

2. Bank Victoria Syariah

3. Bank BRI Syariah

4. Bank Jabar Banten Syariah

5. Bank BNI Syariah

6. Bank Syariah Mandiri

7. Bank Mega Syariah

8. Bank Panin Syariah

9. Bank Syariah Bukopin

\subsection{Metode Penelitian}

Pengujian data dijalankan dengan metode analisis jalur menggunakan program WarpPLS versi 7.0. Program ini dapat digunakan tanpa memerlukan asumsi data terdistribusi normal pada banyak kondisi, konfirmasi teori atau uji hipotesis, untuk melakukan pengujian proporsi, dan melakukan pengujian terhadap hubungan yang belum memiliki landasan teori (Solimun, Fernandes, dan Nurjanah, 2017).

David Garson (2003) dari North Carolina State University menjelaskan bahwa analisis jalulr merupakan pengembangan dari regresi dengan tujuan untuk mengetahui hubungan antara matriks korelasi dengan model hubungan sebab akibat lainnya dalam penelitian. Model penelitian digambarkan dalam bentuk lingkaran dengan anak panah tunggal yang menunjukkan penyebab. Variabel pemberi respon dan variabel penyebab masing-masing dikenakan regresi dengan pembobotan yang membandingkan dengan matriks korelasi yang diteliti kepada semua variabel dan dilakukan perhitungan uji keselarasan statistik. Berdasarkan Sarwono (2011), analisis ini menggunakan koefisien jalur untuk mengetahui besarnya pengaruh antar variabelnya dan digunakan pada hubungan sebab akibat yang menurut pada urutan temporer.

Diagram Alur diperlukan sebelum melakukan pengujian menggunakan WarpPLS sebagai penggambaran model dan pengaruh antar variabel dalam pengujian. Diagram ini menunjukkan hubungan sebab akibat antar variabel yang langsung dengan anak panah. Berdasarkan hubungan antar variabel secara teoritis, dapat dibentuk diagram jalur sebagai berikut :



Gambar 1. Diagram Alur Model Analisis Jalur

Pola hubungan masing-masing variabel dapat diketahui melalui persamaan dari penelitian Pengaruh Risk Profile (FDR), Good Corporate Governance (GCG), Earnings (ROA), and Capital (CAR) terhadap Manajemen Laba (TA) sebagai berikut : 


\section{$\mathrm{TA}=\beta_{1} \mathrm{FDR}+\beta_{2} \mathrm{GCG}+\beta_{3} \mathrm{ROA}+\beta_{4} \mathrm{CAR}+\varepsilon$}

Keterangan :

$\beta_{1}, \beta_{2}, \beta_{3}, \beta_{4} \quad$ : Koefisien yang diestimasi

TA : Total Akrual Manajemen Laba

FDR : Financing to Deposit Ratio

GCG : Good Corporate Governance

ROA : Return On Assets

CAR : Capital Adequacy Ratio

$\varepsilon \quad$ : Standar error atau residual

Goodness of fit model menguji kesesuaian model penelitian yang digunakan dengan data penelitian yang dimiliki. Semakin banyak indikator yang memenuhi kriteria maka model penelitian semakin fit. Di dalam software $W$ arpPLS dalam menentukan model fit dapat dilakukan dengan melihat output general results yang menampilkan sepuluh indicator fit yaitu:

1. Average Path Coefficient (APC) dengan nilai P-values $<0,05$

2. Average R-Squared (ARS) dengan nilai P-values $<0,05$

3. Average Adjusted R-Squared (AARS) dengan nilai P-values $<0,05$

4. Average Block VIF (AVIF) dengan nilai $<5$ dan idealnya 3,3

5. Average Full Collinearity VIF (AFVIF) dengan nilai $<5$ dan idealnya 3,3

6. Tenenhaus $G o F(G o F)$ dengan nilai $\geq 0,1$ yang berarti small; $\geq 0,25$ yang berarti medium, $\geq 0,36$ yang berarti large.

7. Sympson's Paradox Ratio (SPR) dengan nilai $>0,7$ dan idealnya 1

8. R-Squared Contribution Ratio (RSCR) dengan nilai $\geq 0,9$ dan idealnya 1

9. Statistical Suppression Ratio (SSR) diterima dengan nilai $>0,7$

10. Nonlinear Bivariate Causality Direction Ratio (NLBCDR) diterima dengan nilai $\geq 0,7$

Kriteria goodness of fit berdasarkan Solimun et al. (2017) adalah rule of thumb, yaitu tidak berlaku secara kaku dan mutlak. Hal ini dimaksudkan meskipun terdapat satu atau lebih indikator yang tidak diterima kriteria, model pengujian masih dapat digunakan.

Pengujian hipotesis dilihat berdasarkan nilai p-value dengan batas toleransi kesalahan $5 \%$ dan 10\%. Variabel independen dengan nilai p-value dibawah 5\% ataupun $10 \%$ maka memiliki pengaruh signifikan terhadap variabel dependen. Koefisien Jalur yang memiliki nilai negatif (-) menunjukkan pengaruh yang berbanding terbalik. Sedangkan, nilai positif $(+)$ menunjukkan pengaruh yang berbanding lurus.

\section{Hasil dan Pembahasan}

\subsection{Hasil Uji Penelitian}

\section{Hasil Analisis Jalur}

Berdasarkan pengujian yang dilakukan terhadap data penelitian menggunakan metode analisis jalur dengan bantuan aplikasi WarpPLS, berikut merupakan hasil analisis jalur yang tercantum pada diagram alur model penelitian: 


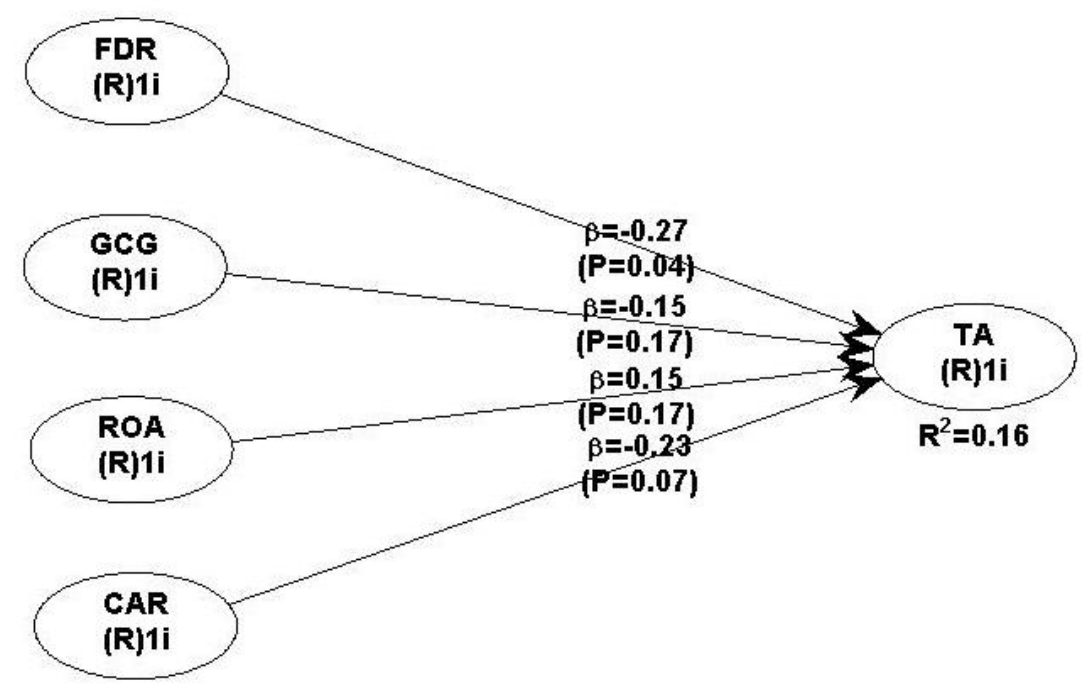

Gambar 2. Hasil Analisis Jalur

Hasil pengujian analisis jalur menunjukkan nilai R-Square dari variabel Manajemen Laba (TA) sebesar 0,16 artinya variabel Manajemen Laba (TA) dapat dijelaskan oleh variabel FDR, GCG, ROA, dan CAR sebesar 16\% sedangkan kekurangannya sebesar 84\% dapat dipengaruhi oleh variabel lain yang tidak digunakan pada penelitian ini. Pengaruh dari variabel Risk Profile (FDR), Good Corporate Governance (GCG), Earnings (ROA), dan Capital (CAR) terhadap Manajemen Laba (TA) sebagai berikut :

1. Risk Profile (FDR) berpengaruh signifikan terhadap Manajemen Laba (TA) pada alpha 0,05 karena memiliki nilai $p$-value sebesar 0,04.

2. Good Corporate Governance (GCG) berpengaruh tidak signifikan terhadap Manajemen Laba (TA) pada alpha 0,05 maupun alpha 0,1 karena memiliki nilai p-value sebesar 0,17.

3. Earnings (ROA) berpengaruh tidak signifkan terhadap Manajemen Laba (TA) pada alpha 0,05 maupun alpha 0,1 karena memiliki nilai p-value 0,17 .

4. Capital (CAR) berpengaruh signifikan terhadap Manajemen Laba (TA) pada alpha 0,1 karena memiliki nilai $p$-value 0,07 .

Berikut merupakan hasil persamaan Risk Profile (FDR), Good Corporate Governance (GCG), Earnings (ROA), dan Capital (CAR) terhadap Manajemen Laba (TA) :

$$
\text { TA }=-0,27 \mathrm{FDR}-0,15 \mathrm{GCG}+0,15 \mathrm{ROA}-0,23 \mathrm{CAR}+\varepsilon
$$

Adapun penjelasan hasil persamaan diatas adalah sebagai berikut :

a. Apabila Risk Profile (FDR) naik sebesar 1 satuan, maka Manajemen Laba (TA) akan mengalami penurunan sebesar 0,27 dengan asumsi variabel lainnya tetap atau konstan.

b. Apabila Good Corporate Governance (GCG) naik sebesar 1 satuan, maka Manajemen Laba (TA) akan mengalami penurunan sebesar 0,15 dengan asumsi variabel lainnya tetap atau konstan.

c. Apabila Earnings (ROA) naik sebesar 1 satuan, maka Manajemen Laba (TA) akan mengalami peningkatan sebesar 0,15 dengan asumsi variabel lainnya tetap atau konstan.

d. Apabila Capital (CAR) naik sebesar 1 satuan, maka Manajemen Laba (TA) akan mengalami penurunan sebesar 0,23 dengan asumsi variabel lainnya tetap atau konstan. 


\section{Hasil Pengujian Goodness of Fit Model}

Uji Goodness of Fit Model ditujukan untuk mengetahui fungsi yang digunakan dalam penelitian sesuai. Hasil pengujian Goodness of Fit Model yang telah dilakukan, sebagai berikut :

Tabel. 1 Hasil Pengujian Goodness of Fit Model

\begin{tabular}{|l|c|c|c|l|}
\hline \multicolumn{1}{|c|}{ Kriteria } & Nilai & $\begin{array}{c}\text { Prob. } \\
\text { Value }\end{array}$ & $\begin{array}{c}\text { Cut-of } \\
\text { Value }\end{array}$ & \multicolumn{1}{|c|}{ Simpulan } \\
\hline Average Path Coefficient (APC) & 0,200 & 0,049 & $<0,05$ & Model Fit \\
\hline Average R-Squared (ARS) & 0,155 & 0,081 & $<0,05$ & Model Tidak Fit \\
\hline Average Adjusted R-Squared (AARS) & 0,046 & 0,195 & $<0,05$ & Model Tidak Fit \\
\hline Average Block VIF (AVIF) & 1,068 & - & $<=3,3$ & Model Fit \\
\hline Average Full Collinearity VIF (AFVIF) & 1,149 & - & $<=3,3$ & Model Fit \\
\hline Tenenhaus GoF (GoF) & 0,394 & - & $>=0,36$ & Model Fit \\
\hline Sympson's Paradox Ratio (SPR) & 1,000 & - & $>=0,7$ & Model Fit \\
\hline R-Squared Contribution Ratio (RSCR) & 1,000 & - & $>=0,9$ & Model Fit \\
\hline Statistical Suppression Ratio (SSR) & 1,000 & - & $>=0,7$ & Model Fit \\
\hline
\end{tabular}

Berdasarkan hasil pengujian dapat dilihat yakni penelitian memiliki model fit dalam kategori cukup baik didasarkan dari 10 indikator yang ada, 8 diantaranya diterima dan 2 diantaranya ditolak. Indikator yang diterima yaitu APC dengan nilai 0,200 dan p-value 0,049, sesuai kriteria yaitu p-value $<0,05$; AVIF dengan nilai 1,068, sesuai kriteria ideal yaitu $\leq 3,3$; AFVIF dengan nilai 1,149, sesuai kriteria ideal yaitu $\leq 3,3$; GoF dengan nilai 0,394 masuk dalam kategori large $\geq 0,36$; SPR dengan nilai 1, sesuai kriteria ideal; RSCR dengan nilai 1, sesuai kriteria ideal; SSR dengan nilai 1, sesuai kriteria ideal; dan NLBCDR dengan nilai 0,750 , sesui dengan kriteria $\geq 0,7$. Sedangkan indikator yang ditolak yaitu ARS dengan nilai 0,155 dan $p$-value 0,081, tidak sesuai kriteria $p$-value $<0,05$; dan AARS dengan nilai 0,046 dan p-value 0,195, tidak sesuai kriteria $p$-value $<0,05$.

\section{Hasil Uji Hipotesis}

1. Variabel Financing to Deposit Ratio (FDR) memiliki nilai koefisien jalur bertanda negatif sebesar 0,27 dengan $p$-value sebesar 0,04. Nilai p-value FDR lebih kecil dari alpha 10\% maka, Ho ditolak dan $\mathrm{Ha}$ diterima. Sehingga, FDR berpengaruh negatif dan signifikan terhadap praktik Manajemen Laba pada Bank Umum Syariah di Indonesia.

2. Variabel Good Corporate Governance (GCG) memiliki nilai koefisien bertanda negatif sebesar 0,15 dengan p-value sebesar 0,17. Nilai p-value GCG lebih besar dari alpha 5\% dan alpha 10\% maka, Ho diterima dan Ha ditolak. Sehingga, GCG berpengaruh negatif dan tidak signifikan terhadap praktik Manajemen Laba pada Bank Umum Syariah di Indonesia.

3. Variabel Return On Asset (ROA) memiliki nilai koefisien bertanda positif sebesar 0,15 dengan p-value sebesar 0,17. Nilai p-value ROA lebih besar dari alpha $10 \%$ dan nilai koefisien tidak sesuai dengan hipotesis maka, Ho diterima dan Ha ditolak. Sehingga, ROA berpengaruh positif dan tidak signifikan terhadap praktik Manajemen Laba pada Bank Umum Syariah di Indonesia.

4. Variabel Capital Adequacy Ratio (CAR) memiliki nilai koefisien bertanda negatif sebesar 0,23 dengan p-value sebesar 0,07. Nilai p-value CAR lebih besar dari alpha 5\% dan lebih kecil dari 
alpha 10\% maka, Ho ditolak dan Ha diterima. Sehingga, CAR berpengaruh negatif dan signifikan terhadap praktik Manajemen Laba pada Bank Umum Syariah di Indonesia.

\subsection{Pembahasan}

\section{Pengaruh Risk Profile terhadap manajemen laba}

Hasil analisis menunjukkan bahwa variabel Risk Profile yang diproksikan dengan rasio Financing to Deposit Ratio (FDR), memberikan pengaruh negatif dan signifikan terhadap Manajemen Laba (TA) pada Bank Umum Syariah periode 2015-2018. Sesuai dengan hipotesis dan teori yang telah dijabarkan bawa rasio ini menilai efektivitas penyaluran pembiayaan atas dana pihak ketiga yang diterima oleh bank. Kegiatan pembiayaan memberikan bagi hasil berupa pendapatan bagi bank, kemudian bank harus mengeluarkan biaya berupa bagi hasil kepada pihak ketiga. Sehingga nilai FDR yang dapat menunjukkan perkembangan pendapatan bank, diduga membuat manajemen bank melakukan manajemen laba dengan lebih intensif.

\section{Pengaruh Good Corporate Governance terhadap manajemen laba}

Hasil analisis menunjukkan bahwa variabel Good Corporate Governance (GCG) yang dinilai melalui peringkat komposit tata kelola perusahaan, memberikan pengaruh negatif dan signifikan terhadap Manajemen Laba (TA) pada Bank Umum Syariah periode 2015-2018. Hipotesis yang dirumuskan tidak sesuai dengan hasil penelitian. Namun, hasil ini sesuai dengan teori yakni tata kelola perusahaan yang baik dapat menurunkan terjadinya manajemen laba karena mendorong terciptanya keadilan, tranparansi, akuntabilitas, dan responsibilitas dalam pengelolaan sebuah perusahaan (Wardhani \& Joseph, 2010). Tidak berpengaruh secara signifikan diduga karena Bank Umum Syariah telah berada pada tingkat tata kelola perusahaan yang baik sehingga bank telah berjalan dengan adil, transparan, akuntabel, dan responsibel. Hal ini terbukti dari kecilnya angka intensitas manajemen laba yang dipraktikkan oleh bank.

\section{Pengaruh Earnings terhadap manajemen laba}

Hasil analisis menunjukkan bahwa variabel Earnings yang diukur menggunakan rasio Return On Assets (ROA) memberikan pengaruh positif dan tidak signifikan terhadap Manajemen Laba (TA) pada Bank Umum Syariah periode 2015-2018. Penelitian dilakukan menggunakan data tahun sebelumnya untuk mengetahui pengaruh ROA dalam praktik manajemen laba pada periode berjalan yang diteliti. Hipotesis yang dirumuskan tidak sesuai dengan hasil penelitian. Namun, hasil penelitian selaras dengan teori mengenai manajemen laba oleh Scott (2009) yang mengungkapkan bahwa motivasi manajemen laba salah satunya adalah Taxations Motivations yaitu motivasi yang didasari atas kebijakan pajak yang berlaku. Perusahaan yang memiliki pendapatan tinggi cenderung melakukan manajemen laba salah satunya sebagai jalan untuk menghindari tagihan pajak yang akan dibayarkan sehingga memiliki hubungan lurus dengan ROA. Hasil tidak signifikan menunjukkan bahwa perubahan rasio ROA tidak memberikan pengaruh yang utama pada keputusan pelaksanaan praktik Manajemen Laba.

\section{Pengaruh Capital terhadap manajemen laba}

Hasil analisis menunjukkan bahwa variabel Capital yang diukur dengan rasio Capital Adequacy Ratio (CAR) memberikan pengaruh negatif dan signifikan terhadap Manajemen Laba (TA) pada Bank Umum Syariah periode 2015-2018. Hipotesis yang dirumuskan sesuai dengan hasil penelitian. Bank dengan rasio CAR yang rendah akan berusaha memenuhi rasio CAR minimum yang ditentukan agar kepercayaan masyarakat kepada bank terjaga dengan adanya jaminan dana mereka aman dengan adanya modal bank yang cukup. Hasil penelitian membuktikan bahwa hal tersebut memotivasi bank untuk mempraktikkan manajemen laba agar sesuai dengan batasan minimal CAR sesuai ketetapan BI. 


\section{Penutup}

\subsection{Kesimpulan}

Hasil penelitian membuktika variabel Financing to Deposit Ratio (FDR) dan Capital Adequacy Ratio (CAR) memiliki pengaruh negatif dan signifikan terhadap Manajemen Laba (TA). Variabel Return On Assets (ROA) memiliki pengaruh positif dan tidak signifikan terhadap Manajemen Laba (TA). Sedangkan, variabel Good Corporate Governance (GCG) memiliki pengaruh negatif dan tidak signifikan terhadap Manajemen Laba.

\subsection{Saran}

Hasil penelitian membuktikan bahwa variabel FDR dan CAR memberikan pengaruh yang signifikan terhadap praktik Manajemen Laba. Sehingga disarankan agar manajemen bank melakukan audit secara berkala dengan teliti dan memberi perhatian khusus kepada variabel tersebut untuk mengurangi dan mencegah terjadinya praktik manajemen laba di kemudian hari pada Bank Umum Syariah di Indonesia.

Penelitian selanjutnya disarankan agar melakukan penelitian dengan data primer agar lebih valid. Selain itu, disarankan untuk memperluas cakupan penelitian dengan menambahkan sampel data, periode penelitian, dan variabel yang diteliti agar mendapatkan hasil yang lebih detail.

\section{Daftar Pustaka}

Faradila, A., \& Cahyati, A. D. (2013). Analisis Manajemen Laba Pada Perbankan Syariah. Jurnal Riset Akuntansi Keuangan, 4(1), 66.

Habbash, murya saad, \& Alghamdi, S. (2015). The perception of earnings management motivations in Saudi public firms. Journal of Accounting in Emerging Economies, $5(1 \mathrm{pp})$.

Hijriyani, N. Z., \& Setiawan, S. (2017). Analisis Profitabilitas Perbankan Syariah di Indonesia sebagai Dampak Dari Efisiensi Operasional. Jurnal Kajian Akuntansi, 1(2), 194-209. https://doi.org/10.33603/jka.v1i2.823

Jasman. (2015). Manajemen Laba: Bukti Empiris pada Perusahaan Perbankan yang Terdaftar di Bursa Efek. Jrak, 11(1), 1-15.

Kasiram, M. (2008). Metodologi Penelitian. UIN-Malang Pers.

Lestari, H. T., Tripuspitorini, F. A., \& Setiawan. (2020). Memprediksi Financial Distress Pada Bank Umum Syariah Periode 2010-2016. Jumal Akuntansi dan Ekonomi FE UN PGRI Kediri, 5(2), 100-111.

Melinda Ros \& Setiawan, S. (2020). Faktor Internal dan Eksternal Perbankan Syariah yang Mempengaruhi Tindakan Perataan Laba. Journal of Applied Islamic Economics and Finance, 1(1), 109-119

Muhammad, A. (2017). Manajemen Laba Pada Laporan Kenangan PT.Bank Bni Syariah Periode 20132014. UIN Syarif Hidayatullah Jakarta.

Nahar, M., \& Erawati, T. (2017). Pengaruh Npm, Fdr, Komite Audit, Pertumbuhan Usaha, Leverage Dan Size Terhadap Manajemen Laba. Akuntansi Dewantara, 1(1), 63-74.

Nasution, M. I. (2017). Faktor-Faktor Yang Mempengarubi Manajemen Laba (Studi Kasus Pada Bank Panin Syariah). In Skripsi (Vol. 3, Nomor 2).

Nurshofyani, A., Pribadi, F., \& Surwanti, A. (2016). Pengarub Rasio Camel Terbadap Praktik Manajemen Laba Pada Bank Di Indonesia. 23-36.

Padmantyo, S. (2010). Analisis Manajemen Laba Pada Laporan Kenangan Perbankan Syariah (Studi Pada 
Bank Syariah Mandiri Dan Bank Muamalat Indonesia). 25.

Prakarsa, R. A., \& Setiawan, S. (2018, October). Pengaruh Profitabilitas, Leverage, Dan Ukuran Perusahaan Terhadap Praktik Perataan Laba (Studi Pada Perusahaan Keuangan Sub Sektor Perbankan Yang Terdaftar Di Bursa Efek Indonesia Periode 2015-2017). In Prosiding Industrial Research Workshop and National Seminar (Vol. 9, pp. 719-727).

Pujiati, L., \& Wahyuningsih, I. (2016). Perbedaan Manajemen Laba Pada Bank Syariah Dan Bank Konvensional Yang Terdaftar Di Otoritas Jasa Keuangan. Akademika, 14(2), 113-118.

Scott, W. R. (2009). Financial Accounting Theory. In Prentice Hall.

Setiawati, K. (2010). Pengaruh Rasio Camel Terhadap Praktik Manajemen Laba Di Bank Umum Syariah (Vol. 12, Nomor 2). http://ijar-iaikapd.or.id/index.php/ijar/article/view/204

Solimun, Fernandes, A. A. R., \& Nurjannah. (2017). Metode Statistika Multivariat Permodelan Persamaan Struktural (SEM) Pendekatan WarpPLS. UB Press.

Suhartanto, D., Farhani, N. H., Muflih, M., \& Setiawan. (2018). Loyalty intention towards Islamic Bank: The role of religiosity, image, and trust. International Journal of Economics and Management, 12(1), 137-151.

Tempo. (2007). Bapepam Denda Direktur Utama AGIS Rp 5 Miliar. Tempo Bisnis. https://bisnis.tempo.co/read/113735/bapepam-denda-direktur-utama-agis-rp-5-miliar

Wardhani, R., \& Joseph, H. (2010). Karakteristik Pribadi Komite Audit dan Praktik Manajemen Laba. Simposium Nasional Akuntansi XIII.

Zoubi, T. A., \& Al-Khazali, O. (2007). Empirical testing of the loss provisions of banks in the GCC region. Managerial Finance, 33(7), 500-511. https://doi.org/10.1108/03074350710753771 